microbial chemotherapy are given for urinary tract infections, and bacterial resistance to broad spectrum antimicrobial agents is common in those wards.${ }^{14}$ Clarification of the role of bacteriuria in the atypical presentation of disease in the elderly might thus allow fewer patients to be treated with antibiotics and so reduce bacterial resistance in wards for the elderly.

The effect of treating all asymptomatic elderly individuals with bacteriuria has not been examined; a very large multicentre study would be required to eliminate confounding variables. The elderly with bacteriuria are a heterogeneous population, and better understanding of underlying causes of urinary infection could result in the identification of subgroups of infected individuals who would benefit from prophylactic treatment.

Senior Lecturer (Medicine),

M J BENDALL

Department of Health Care of the Elderly,

University of Nottingham,

Medical School,

Nottingham NG7 2UH

I Brocklehurst JC, Dillane JB, Griffiths L, Fry J. Prevalence and symptomatology of urinary infections in an aged population. Gerontologie Clinica 1968;10:242-53.

2 Akhtar AJ, Andrews GR, Caird FI, Fallon RJ. Urinary tract infection in the elderly: a population study. Age Ageing 1972;1:48-54.

3 Kaye D. Urinary tract infections in the elderly. Bull NY Acad Med 1980;56:209-20

4 Thysell $\mathrm{H}$. Evaluation of chemical and microscopical methods for mass detection of bacteriuria. Acta Med Scand 1969;185:393-400.

Kass EH. Bacteriuria and the diagnosis of infection in the urinary tract. Arch Intern Med 1957;100:709-13.

6 Sourander LB. Urinary tract infection in the aged. An epidemiological study. Annalis Medicinae Intemae Fenniae 1955;55(suppl 45):1-55S.

7 Bendall MJ. A review of urinary tract infection in the elderly. Antimicrob Chemother 1984;13(suppl B): $69-78 S$.

8 Sourander LB, Ruikka I, Kasanen A. A health survey of the aged with a 5-year follow up. Acta Sociomedica Scandinavica 1970;(suppl 3):5-40S.

9 Dontas AS, Kasviki-Charvati P, Papanayiotou PC, Marketos SG. Bacteriuria and survival in old age. N Engl F Med 1981;304:939-43.

10 Nordenstam GR, Brandberg CA, Oden AS, Svanborg Eden CM, Svanborg A. Bacteriuria and mortality in the elderly population. $N$ Engl f Med 1986;314:1152-6.

11 Suntharalingam M, Seth V, Moore-Smith B. Site of urinary tract infections in elderly women admitted to an acute geriatric assessment unit. Age Ageing 1983;12:317-22.

12 Marketos SG, Papanayiotou PC, Dontas AS. Bacteriuria and non-obstructive renovascular disease in old age. J Gerontol 1969;24:33-6.

13 Isaacs B. Is geriatrics a specialty? In: Arie THD, ed. Health care of the elderty. London: Croom Isaacs B. Is geriatrics
Helm, 1981:224.

14 Grüneberg RN, Bendall MJ. A hospital outbreak of trimethoprim resistance in pathogenic coliform bacteria. $\mathrm{Br}$ Med $\mathcal{J}$ 1979;ii:7-9.

\section{Campylobacter pyloridis: what role in gastritis and peptic ulcer?}

Much excitement has recently been generated by the possibility that Campylobacter pyloridis might be the cause of gastritis and peptic ulcer. ${ }^{12}$ This spiral organism colonises the gastric antrum in $90-100 \%$ of patients with duodenal ulcer, over $70 \%$ of patients with gastric ulcer, and half of patients with non-ulcer dyspepsia. ${ }^{34}$ When present, it is invariably associated with histological evidence of gastritis. ${ }^{5}$

Spiral organisms were seen in the stomach of animals before the turn of the century, ${ }^{6}$ were reported in man in $1906,{ }^{7}$ and raised further interest in $1940,{ }^{8}$ but their possible clinical importance was not recognised until recently. ${ }^{9.11} C$ pyloridis, ${ }^{12}$ a microaerophilic spiral bacterium, is like many other campylobacters and shows some antigenic cross reactivity, ${ }^{2}$ but it differs from others metabolically, morphologically, and in its chemical structure. ${ }^{1}$

The organisms are found on the surface of gastric epitheliäl cells even when acidity is normal-they are protected from acid by the overlying mucus layer and the alkaline secretion of the epithelial cells. ${ }^{13}$ They are mobile in highly viscid material ${ }^{14}$ and appear to be specially adapted to the mucus layer above these particular cells as they are not found in areas of intestinal metaplasia within the stomach, and when identified in the duodenum are found only in areas of gastric metaplasia. ${ }^{10}$ Ultrastructural studies show adherence pedicles at points of membranous adhesion ${ }^{15}$; microvilli are absent or depleted, and intracellular oedema is prominent. These appearances are reminiscent of intestinal epithelial cells infected by enteropathogenic Escherichia coli.

Is $C$ pyloridis pathogenic? Data from many different centres have confirmed the association with active gastritis, ${ }^{12}$ but the organisms are less often found in gastritis secondary to duodenogastric reflux ${ }^{16}$ and pernicious anaemia. ${ }^{17}$ These data, together with the ultrastructural appearances, strongly support a primary aetiological role. Further support comes from an experiment carried out by a normal volunteer who developed an acute self-limiting dyspeptic syndrome with acute gastritis after swallowing the bacteria. ${ }^{18}$ Other evidence links $C$ pyloridis infection with an epidemic of hypochlorhydric gastritis in 17 of 37 volunteers who underwent acid secretion studies with a $\mathrm{pH}$ electrode that had not been sterilised between experiments. ${ }^{19}$ Eradication of $C$ pyloridis with antibiotics or bismuth leads to histological improvement ${ }^{4}$ but relapse is common. Serum IgA and IgG titres to $C$ pyloridis are appreciably raised in patients with campylobacter, ${ }^{2021}$ and local gastric juice antibodies are also present in some of these. 22

The clinical relevance of the strong association between gastritis and $C$ pyloridis is, however, controversial as gastritis occurs in many of the normal population ${ }^{23}$ and campylobacter associated gastritis has been reported in a quarter of normal volunteers. More interesting is its relation with peptic ulcer. ${ }^{410}$ Numerous studies have confirmed that campylobacter associated gastritis is present in virtually all non-iatrogenic cases of duodenal ulcer. $C$ pyloridis may infect the islands of metaplastic gastric epithelium found in the duodenum, thereby weakening the mechanisms which normally protect these cells from acid attack, which leads to a breakdown in mucosal integrity and ulceration. ${ }^{24} \mathrm{~A}$ similar sequence in the stomach leads to gastric ulceration. The evidence for this hypothesis remains circumstantial, but metronidazole, to which $C$ pyloridis is sensitive, has had a beneficial effect in both gastric and duodenal ulceration. ${ }^{25}$ Further, the lower recurrence rate when duodenal ulcers are healed with colloidal bismuth subcitrate rather than acid reducing drugs may be related to the effect of bismuth on $C$ pyloridis. ${ }^{26}$

General Physician,

Gastroenterology Unit,

General Infirmary,

Leeds LS1 3EX

1 Goodwin CS, Armstrong JA, Marshall BJ. Campylobacter pyloridis, gastritis, and peptic ukeration. $\mathcal{F}$ Clin Pathol 1986;39:353-65.

2 Rathbone BJ, Wyatt JI, Heatley RV. Campylobacter pyloridis-a new factor in peptic ulcer disease? Gut 1986;27:635-41.

3 Marshall BJ, Warren JR. Unidentified curved bacilli in the stomach of patients with gastritis and peptic ulceration. Lancet 1984; i:1311-4.

4 Marshall BJ, McGechie DB, Rogers PA, Glancy RJ. Pyloric campylobacter infection and gastroduodenal disease. Med J A us 1985;142:439-44.

5 Tytgat GNJ, Langerberg ML, Rauws WE, Rietra PJGM. Campylobacter-like organisms (CLO) in the human stomach. Gastroenterology 1985;88:1620.

6 Bizzozero G. Ueber die schlauchformigen drusen des magendarmkanals und die beziehungen izzozero G. Ueber die schlauchformigen drusen des magendarmkanals und die beziehures
ihres epithels zu dem obertflachenepithel der schleimhaut. Arch $f$ Mikr Anat 1893;42:82.

7 Krienitz $W$. Ueber das auftreton von spirochaten verschiedener form im mageninhalt bei carcinoma ventriculi. Deutsche Med Wchnschr 1906;28:872.

8 Freedberg AS, Barron LE. The presence of spirochetes in human gastric mucosa. Am J Dig Dis 1940;7:443-5.

9 Steer HW, Colin-Jones DG. Mucosal changes in gastric ulceration and their response to carbenoxalone sodium. Gut 1975;16:590-7. 
10 Steer HW Surface morphology of the gastroduodenal mucosa in duodenal ukeration. Ge 1984;25:1203-10.

11 Warrea JR, Marshall B. Unidentified curved bacilli on gastric epithelium in active chronic gastritis. Lance 1983;i:1273-5.

12 Marshall BJ, Royce H, Annear DI, el al. Original isolation of campylobacter pyloridis from buman gastric mucosen. Microbios Laters 1984;25:83-8.

13 Allen A, Garner A. Mucus and bicarbonate secretion in the stomach and their possible role in mucosel procection. Guel 1980;21:249-62.

14 Hazell SL, Lee $\Lambda$. The adaption of motile strains of Campylobecter pyloridis to gastric mucus and their association with gastric epithelial intracelluhr speces. In: Pearson AD, Skirrow MB, Lior H, Rowe B, eds. Cenpylablacter III: procentings of the thind intemational workshop on H, Rowe B, eds. Campylabacter III: proceediegs of the thind intemational wort

15 Goodwin CS, Armstrong JA. Will antibecterial chemothernpy be efficacious for gastritis and peptic ulcer? I Antinicreb Chemocher 1986;17:1-4.

16 O'Connor HJ, Wyatt JI, Dixon MF, Axon ATR. Campylobacter like organisms and reflux gastritis. J Clin Pathol 1986;39:531-4.

17 O'Coanor HJ, Axon ATR, Dixon MF. Campylobacter-like onganisms unusual in type A (pernicious anaemia) gastritis. Lance 1984;ii:1091.

18 Marshall BJ, Armstrong JA, McGechie DB, Glancy RJ. Attempt to futfil Koch's postulates for pyloric campylobecter. Med J Aus 1985;142:436-9.

19 Ramsay EJ, Carey KV, Peterson WL, et al. Epidemic gastritis with hypochlorhydria. Gastroenterdosy 1979;76:1449-57.

20 Kaldor J. Tee $W$, McCarthy P, Watson J, Dwyer B. Immune response to Campylobecter pyloridis in patients with peptic ulceration. Lancet 1985; 921.

21 Rathbone BJ, Wyatt JI, Worstey BW, et al. Systemic and local antibody responses to gastric Campylobecter pyloridis in non-uker dyspepsia. Gut 1986;27:642-7.

22 Wyatt JI, Rathbone BJ, Heatley RV. Local immune response to gastric campylobacter in nonukeer dyspepsia. I Clin Path (in press).

23 Strickland RG. Chronic gastritis. In: Bouchier IAD, Allan RN, Hodgson HJF, Keighley MRB ods. Textbook of gastroenterology. London: Baillière Tindall, 1984:113-24.

24 Hazell SL, Loe A. Campylobacter pyloridis, urease, hydrogen ion back diffusion, and gastric ukers. Lancet 1986; ii: $15-7$.

25 Diaz MQ, Escobar AS. Metronidazole versus cimetidine in treatment of gastroduodenal ulcer. Lancet 1096;i:907.

26 McLean AJ, Harrison PM, Ioannides-Demos LL, Byrne AJ, McCarthy P, Dudley FJ. Microbes, peptic ulcer, and retapse rates with different drugs. Lancet 1984;ii:525-6.

\section{Isolating the gene for Duchenne muscular dystrophy}

Despite much work on muscle and other tissues we still have no clear indication of what the primary defect is in Duchenne muscular dystrophy, and this makes rational approaches to treatment and prevention difficult. The new recombinant DNA techniques allow identification of a gene without requiring information on what that gene does, and these have allowed research to break out of what might have been stagnation and given five years of remarkable progress.

The first clue came from the observation of a rarity: the occurrence of several cases of Duchenne muscular dystrophy in girls carrying a chromosome rearrangement affecting the $\mathrm{X}$ chromosome. ${ }^{1}$ Initially these were thought likely to be incidental changes, but as other cases were reported it became clear that the breakpoint on the $\mathrm{X}$ chromosome was at the same site in each-the central area of the short arm of the $\mathrm{X}$ known as band $\mathrm{p} 21 .{ }^{2}$ Over 15 such cases are now known, and this constancy has remained, leaving no doubt that the break is at the site of the Duchenne muscular dystrophy gene.

Soon after the recognition of these cases it became possible to produce markers for the Duchenne muscular dystrophy gene that could be studied in families. ${ }^{3}$ These DNA markers -inherited variations in DNA sequence recognised by producing fragments of different size and known as restriction fragment length polymorphisms-could be localised to the $\mathrm{X}$ chromosome by physical methods and then tested in families with the disorder to show whether the markers had been inherited in parallel with the disease. The year 1982 saw the first such markers linked to Duchenne muscular dystrophy, ${ }^{4}$ and in 1983 a second marker was placed on the opposite side of the gene. ${ }^{5}$ Both firmly placed the Duchenne muscular dystrophy gene at p21, the same site as that suspected from the girls with chromosome defect.
Furthermore, the gene for the milder "Becker" form of muscular dystrophy (previously thought to be quite separate) proved to be at the same site. ${ }^{6}$

These markers opened the way to prediction for the Duchenne muscular dystrophy gene, since by typing the markers in a family - particularly when both markers could be used together-the presence of the Duchenne muscular dystrophy gene itself could be inferred.' The search was now on for closer and more informative markers, and within a year at least seven had been detected, greatly increasing the proportion of families who could be helped by carrier detection, ${ }^{8}$ and allowing also the possibility of early prenatal prediction by chorion biopsy in occasional cases.'

At this stage, around mid-1985, the suspicion became strong that the Duchenne muscular dystrophy gene was not a conventional one. Despite some of the DNA markers being physically close, all showed relatively frequent recombination between marker and disease, ${ }^{10}$ suggesting that the gene might be in an unstable site with much mutation and rearrangement. Recent developments have shown that this is indeed the case, thanks to two remarkable pieces of research that have brought us to the threshold of the gene itself.

The first of these, by Lou Kunkel and colleagues in Boston, was based on the study of a boy who had both Duchenne muscular dystrophy and a visible chromosome deletion." "2 When DNA sequences isolated from the deleted region were tested against others from patients with "ordinary" Duchenne muscular dystrophy it became clear that some of them were missing the Duchenne muscular dystrophy gene, even though they were chromosomally normal. About $7 \%$ of cases are now known to be associated with gene deletions-the first step in molecular analysis of the defect. At the same time Worton and colleagues in Toronto were able to isolate and clone the DNA from the breakpoint on the $\mathrm{X}$ chromosome of one of the girls with muscular dystrophy and a chromosome translocation. ${ }^{13}$ As predicted this DNA sequence proved to be integrally related to the Duchenne muscular dystrophy gene, showing deletions in most of the cases which were missing Kunkel's "pERT" probe.

These two experiments, reaching the same endpoint from different approaches, might have been expected to have solved the problem and allowed the gene itself to be fully analysed and its product identified. This has not happened, however, and we seem to be dealing with a very large region of DNA (perhaps several million base pairs) in which a change at different points may result in Duchenne or Becker muscular dystrophy. So far there is no sign of a single functional gene in this region.

How does this answer the questions for clinicians looking after families with Duchenne and Becker muscular dystrophy? The first group for whom there has been a real advance is those in whom a gene deletion is present. Here one can offer carriers an accurate and specific first trimester prenatal diagnosis, so it is most important that such boys and their relatives are carefully tested. For the majority not showing a deletion there remains a finite error of around $5 \%$ even using the new markers integrally related to the gene. Nevertheless, most carriers may now be predicted accurately by combining DNA analysis with the older approach of creatine kinase testing. If prenatal diagnosis is undertaken the family must realise that we still do not have a totally accurate prediction, though a $95 \%$ accuracy rate will be acceptable to some. For all families the rapid progress of the past five years is a cause for real optimism, since we are now 